\title{
Purported use and self-awareness of cognitive and metacognitive foreign language reading strategies in tertiary education in Mozambique
}

\author{
Manuel Cabinda
}

Eduardo Mondlane University (UEM), Mozambique

\begin{abstract}
This paper explores the results of a Survey of Reading Strategies (SORS)-based questionnaire administered to 28 university student participants. The study is carried out in a post-colonial multilingual context, Mozambique. The main aims of the paper are to assess the degree of purported use and awareness of participants own use of reading comprehension skills and strategies in a foreign language (English). The participants were tested for their reading text comprehension using an IELTS comprehension test (Cabinda, 2013). The results revealed low reading comprehension levels. Results contrast with results from the SORS-based questionnaire (Cabinda, 2013) which revealed claims of use of a wide range of cognitive, metacognitive and supply strategies - aspects of high level reading ability and text comprehension. Conclusions show that the participants used or claimed to chiefly use metacognitive and cognitive reading strategies equally, matching the behaviour of good readers, but they also reported a high degree of supply strategies to construe meaning from text, mainly code-switching, translation and cognates. The latter confirms results from studies by Jimenez et al. (1995, 1996) and Zhang \& Wu (2009), yet do not conclusively show a correlation between the participants' degree of text comprehension and their effective use of reading skills and strategies to construe meaning. Further conclusions show that the reported high use of these LI (Portuguese or other) related supply strategies (not used by English LI readers) does not aid their reading comprehension.
\end{abstract}

Key words: EFL, reading strategies, cognition, metacognition, awareness

\section{Introduction}

The quest to determine specific reading strategies used by learners of English in an Academic Purpose (EAP) or English for Specific Purpose (ESP) or even in English as a Foreign Language (EFL) multilingual context, and the extent to which these are known to the users, governs the present study. Results from this study intend to fill the gap advanced by Bernhardt's (2005, 20II) compensatory model of reading in a foreign language, which claims the existence of ' $50 \%$ unexplained variance'. Clearly, Bernhardt (20II) shows that there is a correlation between the various dimensions of reading in a second language, but still claims the existence of an unexplained area, closely related to comprehension strategies, among other aspects. 


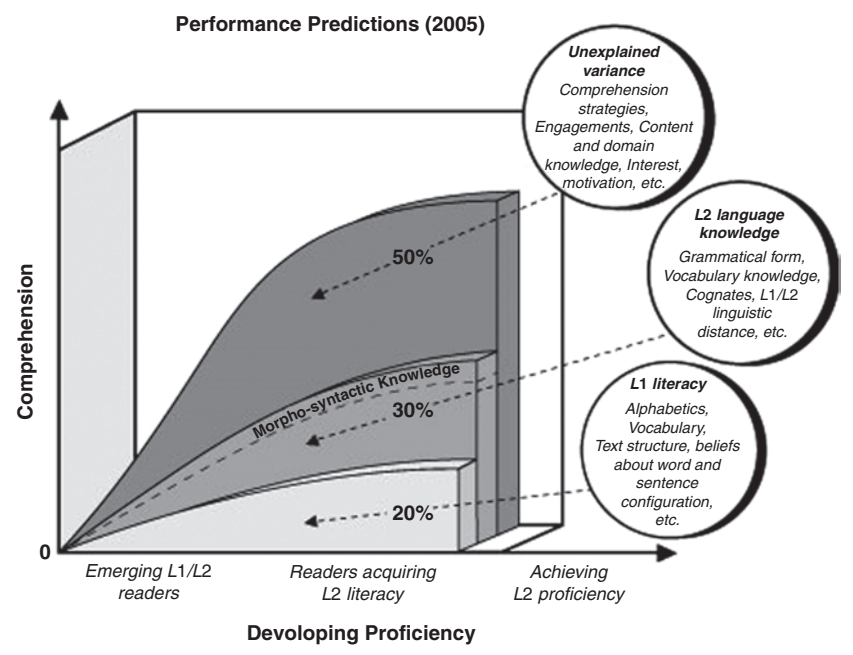

Figure 1: Bernhardt's (2011) Compensatory model of reading in second language.

The Compensatory model of reading in a second language has evolved from Bernhardt's I99I proposition and the developments of her 2005 work. This model essentially proposes proved suggestions and claims on how second language reading operates. It uses results from LI reading studies as the basis to study L2 reading. The model clearly explains how reading in a second language has been analyzed and results borne, i.e. the understating of some of the problems in FL reading which were referred to as 'problem of syntax' or 'prior knowledge', or even a problem related to word-level and phonological issues (Bernhardt, 2005). With the progression of research in the field of reading, Bernhardt proposed the evolved $201 \mathrm{I}$ model which clearly shows that the above issues have been resolved, but there is still a ' $50 \%$ unexplained variance' that needs explaining in terms of how comprehension strategies, engagement, content and domain knowledge, interest, and motivation operate and assist reading and text comprehension in a foreign language and their link with LI reading.

The literature shows that most of the research in L2 (Second Language) and/or FL (Foreign Language) reading strategies has involved students at lower levels of proficiency or enrolled in secondary and pre-university schools and has resulted in the assumption amongst language practitioners that literature on reading strategies used by advanced or proficient second or foreign language learners is not visible enough, possibly due to some research findings 'suggest[ing] that reading problems are closely associated with the level or proficiency in the target language [English]' (Sheorey \& Mokhtari, 200I:434).

These problems can also be associated with discussion in the field about the term 'second' in Second Language Acquisition. Kerfoot (2009) has referred to this term as a source of problems in the South African education context where post-Apartheid education policy has led to the adoption of the term 'English as an additional language' (EAL) in 
the formal adult education context as well as in the school language curriculum context. There are some similarities between the South African and Mozambican multilingual contexts. English can also be seen as the second language of instruction in Mozambique, after Portuguese, in late primary and secondary school through to university level. I, however, would agree with Kerfoot (2009) when she argues that the term 'second' does not take account of existing multilingual repertoires or previous language learning experiences (Kerfoot, 2009:I8). The LI pool of languages in Mozambique, consisting essentially of Bantu languages, has not been studied particularly in terms of their role in the development of the target language, English. In post colonial Mozambique, Portuguese is the main language of instruction while it is the mother tongue to some, but a second (or even third or fourth) language to most of its inhabitants. Therefore English constitutes a FL or an additional language for most of the students in the current study.

The dearth of research in FL reading strategies at tertiary level has recently resulted in several research studies, but very few have concentrated upon documenting the types of metacognitive reading strategies of proficient native and non-native readers (Mohktari \& Reichard, 2004; Bernhardt, 2005, 20II) and even fewer involve Portuguese speakers (Vidal, 2002). Most studies are in the socio-cultural and multilingual and educational context of the Asian sub-continent (with non-cognate languages to English or Portuguese) (Sheorey \& Mohktari 200I; Knight et al., I985; Block, I986, I992; Carrel et al., I989; Pritchard, I990; Anderson, I99I; Zhicheng, I992; Auerbach \& Paxton, I997; Zwiers, 2008; Brown \& Rodgers, 2009). Examples are Feng and Mokhtari (I998) who studied Chinese university students and showed these to be using wide-ranging supply strategies while reading in English and in Chinese and also revealed higher frequency use of reading strategies while reading in the second language (L2) than in their first language (LI) and when reading difficult texts in comparison to those used when reading easy texts. Jiang and Kuehn (200I) looked at the correlation between metacognitive reading strategies and the use of reading strategies by first and second-language readers of English and showed successful readers to be users of larger numbers of cognitive and meta-cognitive reading strategies, using a number of very important reading strategies (setting the purpose for reading, prediction, summarizing, questioning, use of text structural features, self-monitoring and so on) which learners use to a greater extent to plan, control and evaluate their own understanding of text.

Zhang \& Wu (2009) reported the use of three categories of strategies, global, support, and problem solving at a high-frequency level where high-proficiency students outperformed the intermediate and the low-proficiency ones in two categories of reading strategies (global and problem solving) but no statistically significant difference was found among the three categories of students when using support strategies. There is an indisputable relationship between meta-cognitive awareness of reading strategies and their performance in reading test of successful readers as shown by Nezhad (2006). These are a few examples of studies done in Asian contexts which far outnumber the few studies done in a similar field involving Portuguese LI or FL speakers. 
Thus the present study has been designed in order to fill the gap in the field, particularly in the Portuguese speaking context, and to further understand what takes place at the Eduardo Mondlane University (UEM) with UEM learners using authentic reading texts and other materials written in a foreign language, English.

\section{Reading skills and strategies}

Typical reading strategies in LI and L2/FL include the use of the index and scanning the relevant paragraphs; the use of the index and/or contents and reading the relevant sections; skimming the whole text or part of the text; reading carefully and taking notes. These can often be confused or used interchangeably with what are sometimes referred to as skills. A skill is an acquired ability that operates largely subconsciously, whilst a strategy is a conscious procedure carried out to solve problems in the comprehension process, as Pang (2008) puts it. Hence, strategies, or rather metacognitive strategies, being conscious means to which readers resort in order to monitor their own reading process, can be used to evaluate the effectiveness of their cognitive strategies. There is a clear association between reading strategies and metacognition knowledge. The latter (also called metacognitive awareness), first introduced by Flavell (I976), is defined as "one's knowledge concerning one's own cognitive processes and outcomes or anything related to them", and further explanation refers to "the active monitoring and consequent regulation and orchestration of these processes in relation to the cognitive objects or data on which they bear, usually in the service of some concrete goal or objective" (Flavell, I976:232). Metacognition is generally fundamental in a variety of areas, such as oral skills, reading, writing, language acquisition, attention, memory, and social interactions (Flavell; 1977); Flavell, Miller, and Miller (2002). Metacognitive language and/or awareness also refers to what learners and readers know about their own level of thinking involved in active control over the thought process used in learning situations. Hence it refers to their own awareness concerning their own plan to approaching a learning task, monitoring comprehension and evaluating the progress towards the completion of a task (Wenden, I99I; Zhang, 200I; Chamot, 2005). I thus seek to understand how aware the participants are of their use and purported use of reading strategies. The statements in the questionnaire given to the participants can be found in Table $\mathrm{I}$ in the methodology section below.

\section{Methodology: The Cognition and Metacognition Questionnaire}

The current study uses a two-part cognition and metacognition questionnaire adapted from two major sources: statements on a reading strategies table in a questionnaire on 'How you read in class at Oxford Brooks and how you used to read in China' developed by Li and Errey (2008) and the Survey of Reading Strategies (SORS ${ }^{\mathrm{r}}$ ) based on the 
IO-I2-6 reading strategies taxonomy by Sheorey and Mokhtari (200I) and MetacognitiveAwareness-of-Reading-Strategies Inventory (MARSI $\left.{ }^{2}\right)$. SORS measures the three broad categories of reading strategies, namely metacognitive strategies, cognitive strategies, and support strategies.

The original SORS questionnaire was adapted using data from the reading skills/ strategies classifications and/or taxonomies by Rosenthine (I980), Munby (I980), Weir (1984), Mokhtari and Reichard (2004). Some wording from Sheorey and Mokhtari's (200I) SORS deemed to be rather difficult for the FL readers (in the context of the current study) and could confuse the primary goal of the questionnaire were modified. These were in the form of phrasal verbs that could potentially lead to a language competence test instead of a reading skills/strategies finding. An extra point on the Likert scale was added to the original format of SORS, which is a five-point Likert scale tool. Li and Errey's (2008) statements matched the strategies in SORS thus providing grounds for adapting a suitable table for the current study. Li and Errey's (2008) 35 statements were reduced to 26 based on my understanding of the different types of strategies and the contents in the I0-I2-6 strategy taxonomy (Sheorey \& Mokhtari, 200I). Li and Errey (2008) divide reading strategies into cognitive and metacognitive strategies, and subdivide them further into i) academic support strategies/skills, ii) text comprehension strategies/skills, and iii) language focus skills/strategies). Some of the wording was altered and different lexical items used (...by clues to using clues in numbers I and 2; look up to check in 3; overview to scan in I5), and some clauses added to facilitate participants' comprehension of the questions (in statements 3 and 9, for example). Li and Errey's columns for each setting of the study, China and Brooks University, were transformed in the "Circle a number" column. Further, although the statements reflect the I0-I2-6 taxonomy of reading strategies by Sheorey and Mohktari (200I) the content in the table has been adjusted to minimize repetitive information.

A part of the questionnaire (part II) aimed at assessing the participants' meta-awareness was added, i.e. to find out whether participants were consciously aware of their (conscious) use of reading skills and/or strategies to resolve comprehension problems when attempting to construe meaning and/or monitor their reading process. This metaawareness can be measured by an instrument called MARSI, Metacognitive-Awarenessof-Reading-Strategies Inventory, which was developed to measure native English speakers' awareness and use of reading strategies while reading academic or school-related materials (Sheorey \& Mokhtari, 200I), but was considered too difficult for the participants in the current study. Neither the original MARSI nor the original SORS were used in my questionnaire because the participants in my study are not native speakers nor L2 speakers but rather $\mathrm{L}_{3}$ or FL speakers. Thus using a non-adapted version of MARSI and/ or SORS would be counterproductive. Reichard (2002) and it is a tool for measuring native English speaking students' awareness and conscious use of reading strategies while reading academic or related school materials. 


\begin{tabular}{|c|c|}
\hline Code & Statement reflecting reading strategy usage \\
\hline I & I guess meanings of new words using context. MET9 \\
\hline 2 & I guess meanings of new words using clues from word root or affixation. COGI2 \\
\hline 3 & $\begin{array}{l}\text { I assess the need to check the meaning in a dictionary or to ignore words that I don't } \\
\text { know and continue reading. COG9 }\end{array}$ \\
\hline 4 & $\begin{array}{l}\text { I find words with similar meaning to replace [difficult] words to help me understand } \\
\text { the text. SUP } 3\end{array}$ \\
\hline 5 & I identify key words/expressions used by the author to organize text MET4 \\
\hline 6 & $\begin{array}{l}\text { I read difficult sentence (s) repeatedly until I understand then I continue reading the } \\
\text { rest of the text. COGII }\end{array}$ \\
\hline 7 & I ignore difficult sentence $(\mathrm{s})$ and continue reading. $\mathrm{MET}_{5}$ \\
\hline 8 & $\begin{array}{l}\text { I analyse the grammatical structure of a difficult sentence to understand the message. } \\
\text { COGio }\end{array}$ \\
\hline 9 & $\begin{array}{l}\text { I make note-cards or files after reading a text to remember/revise details about the } \\
\text { text. SUP } 3 \text { /SRS }\end{array}$ \\
\hline Io & I take notes while reading. SUPI \\
\hline II & I highlight/underline important sentences/parts of the text while reading. SUP2 \\
\hline $\mathrm{I} 2$ & I say the words out loud or pronounce them in my mind while reading. COG2 \\
\hline I3 & I translate words into Portuguese while reading. SRS \\
\hline I4 & I scan the text for purpose before reading for details .MET2/MRS \\
\hline I5 & I use graphics like charts, figures, punctuation to help me understand the text. MET8 \\
\hline I6 & I recognize the structure or organization of a text. MET4 \\
\hline 17 & I use a table, a chart or bullet to summarize the structure of the text MET6 \\
\hline I8 & I use key words or topic sentences to make predictions. MET9+Io/MRS \\
\hline I9 & I make up imaginary scenes or conjure scenarios with words while reading. COG8 \\
\hline 20 & I read sentence by sentence to understand a paragraph. $\mathrm{COG}_{3}$ \\
\hline $2 \mathrm{I}$ & $\begin{array}{l}\text { I skim the text to get a general idea and scan for specific details while reading to } \\
\text { comprehend a text.SUP5 }\end{array}$ \\
\hline 22 & I use prior knowledge to understand new information COGI \\
\hline 23 & I set a goal/purpose before reading a text METI \\
\hline 24 & $\begin{array}{l}\text { I vary my reading approach/style with each text and according to goal or purpose. } \\
\text { COG } 5\end{array}$ \\
\hline 25 & I reflect upon what has been learnt from the text and apply results critically. COG7 \\
\hline 26 & I identify my weakness to improve reading ability MRS \\
\hline
\end{tabular}

$M E T=$ metacognitive strategies; $C O G=$ cognitive strategies; $S U P=$ supply or support strategies; SRS = supply

reading strategies; MRS = metacognitive reading strategies. (Table adapted from Li \& Errey 2008).

Table 1: Statements reflecting reading strategy usage in the questionnaire. 


\section{Reliability and Validity of Questionnaires}

The validity of using a questionnaire as a research tool has been widely discussed in the research community (Naiman et al., I978; O'Malley et al., I985; Wenden, I985; Ramirez, I986; Oxford et al., I987; Johnson, I994; Presser et al., 2004; Coleman \& Briggs, 2005; Saw \& Ng, 200I; Sushil \& Verma, 20I0; Cohen et al., 20II). The power of the participant completing the questionnaire in terms of whether s/he chooses to complete it or not and whether s/he gives unforeseen responses is seen as the 'empowerment' feature of this instrument. The need to pilot the tool and systematically following sequential steps before and during the administration of the questionnaire to ensure its reliability and validity as far as possible is of the utmost importance. Important steps in the design of the tool range from the decision as to what to elicit from the questionnaire, the precise wording (simple, general and or specific), clarity in terms of measuring the participants' responses and the data obtained, to the avoidance of ambiguity, imprecision and assumptions (Cohen et al., 20II), as well as the time participants should spend completing it (Johnson, I994; Coleman \& Briggs, 2005; Cohen et al., 20II).

The reliability and effectiveness of questionnaires as a research tool is also stressed by Johnson (1994). There are dangers in using questionnaires related to the number of participants not completing or returning the questionnaire at all, and to participants not giving answers or giving answers that may present them in a better light (Jobe \& Mingay, I989). This 'empowerment' feature does not however hinder the use of the questionnaire as an effective tool for research; its effectiveness comes with how such a tool is validated and this depends on its reliability (Saw, Ng, 200I; Presser, S. et al., 2004; Sushil \& Verma, 20I0). Given the different types of questionnaire used in different contexts, every questionnaire should undergo its own validation process.

To validate the questionnaire used in the present study we made sure that it had a reduced degree of bias ${ }^{3}$ by detecting ambiguities and misinterpretations; we also preexamined the feasibility, acceptability, time needed to respond, cost effectiveness etc. by testing it with a few participants. Further, we examined the variations in response, and in so doing, maximised the possibility of collecting better quality data as posited by Sushil \& Verma (20I0). Piloting helped in rectifying any weaknesses in the questionnaire.

\section{The Research population}

There were a total of 28 participants to this study, all Eduardo Mondlane University (Maputo, Mozambique) undergraduate students in the Faculty of Arts and Social Sciences that had sat an IELTS reading test in an earlier study (Cabinda, 20I3), of which six (21.4\%) are female. There are ig Bantu LI speakers and the remaining seven are Portuguese LI speakers. Two participants did not state their first language (LI) (See Cabinda, 20I3). The 
results of the comprehension test (of which the maximum score was 40) revealed lowest and highest marks of 7 out of 40 and 23 out of 40, respectively. Only seven participants had a result equal or above $50 \%$, meaning that only 7 participants obtained IELTS standards for reading comprehension that are situated in band 4.5-5.5 (See Cabinda, 2013: Table I). The general comprehension average (Cabinda, 20I3: Table 2) was low at 20.7I for those with a result $\geq 50 \%$ and $\mathrm{I} 2.04$ for those with a result $<50 \%$, i.e. the mean for the total participants was very low at $\mathrm{I} 6.57 \%$ of text comprehension.

\section{Procedures}

The participants were handed the adapted two-part questionnaire as soon as they had finished the IELTS reading test (Cabinda, 20I3) and were given a day or two to complete it. The researcher arranged to meet with the participants in a place and time suitable for the majority of them. Prior to this action, the aims of the study and the specific aim of the research tool were explained to the participants. The questionnaires were also piloted and participants' doubts and confusions addressed and clarified. The participants were alerted to the fact that no monetary or material compensation would result from their participation and that they were free to leave the study at any time. They were however reminded of the fact that credits would be awarded to their final marks for time spent on this research project. Letters of consent signed at the beginning of the process were valid for all the stages of the study as had been previously explained to all participants. The completed questionnaires were collected a day or two days later and the participants were then advised to remain available, if they wanted to, to take part in subsequent phases of the study leading to my doctorate thesis, i.e. a Think Aloud study (Cabinda, 20I4).

\section{Results}

The results were plotted onto tables to show the total number of statements circled per respondent per level of reading strategy classification. These are in a systematized manner for clearer understanding of the numbers and strategy usage claims (See Tables 2 and 3). Results from Part II of the questionnaire revealed that from the 28 participants who had been given the questionnaire, only 20 handed them back. The other 8 participants did not state any reasons for not handing back the questionnaires. No attempt was made to find out the reason behind this given the participants' prerogative to discontinue at any time. Results are plotted in table 2 and this shows the total numbers (highlighted) that represent the sum total of choices circled by participants per statement; the significance is explained later. The evidence revealed a majority of the choices around points 3-5 of the Likert scale, i.e. the most used strategies have the highest number of frequency hits. The choices under points I and 2 on the Likert scale (I never do that and I usually don't do that) should not be taken lightly. 


\begin{tabular}{|c|c|c|c|c|c|c|}
\hline \multirow[t]{2}{*}{ Code of Participant } & \multicolumn{6}{|c|}{ How true? Total statements circled/crossed } \\
\hline & 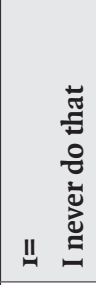 & 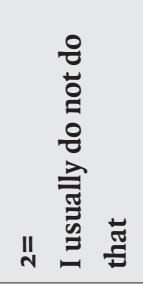 & 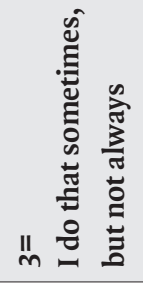 & 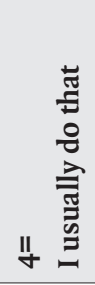 & in & |l \\
\hline OoI & 0 & 3 & 5 & II & 6 & 0 \\
\hline 002 & 7 & 6 & 7 & 5 & o & 0 \\
\hline 003 & I & 2 & 8 & 5 & 9 & I \\
\hline 004 & 2 & 9 & 9 & 4 & o & 0 \\
\hline 005 & 6 & 2 & I & 7 & 9 & 0 \\
\hline \multicolumn{7}{|l|}{006} \\
\hline \multicolumn{7}{|l|}{007} \\
\hline 008 & 5 & 5 & 6 & 4 & 2 & 4 \\
\hline \multicolumn{7}{|l|}{009} \\
\hline oIO & 2 & 3 & I0 & 5 & 5 & 0 \\
\hline OII & 5 & 0 & 7 & 2 & $\mathrm{I} 2$ & 0 \\
\hline OI2 & 2 & 2 & 9 & 5 & 8 & 0 \\
\hline 013 & 5 & 4 & 6 & 5 & 5 & 0 \\
\hline \multicolumn{7}{|l|}{ OI4 } \\
\hline 015 & 0 & I & 8 & 9 & 7 & 0 \\
\hline \multicolumn{7}{|l|}{ oI6 } \\
\hline 017 & 6 & 0 & I6 & 0 & 4 & 0 \\
\hline \multicolumn{7}{|l|}{ oI8 } \\
\hline \multicolumn{7}{|l|}{ oI9 } \\
\hline 020 & 2 & I & 7 & 6 & 8 & I \\
\hline \multicolumn{7}{|l|}{ O2I } \\
\hline 022 & 2 & 3 & 4 & 9 & 9 & 0 \\
\hline 023 & 5 & 0 & 8 & 3 & IO & 0 \\
\hline 024 & I & I & 9 & $\mathrm{I} 2$ & I & I \\
\hline 025 & 4 & 4 & 4 & 5 & 6 & 3 \\
\hline 026 & 2 & 2 & IO & 7 & 5 & 0 \\
\hline 027 & 4 & 4 & 6 & 5 & 3 & 4 \\
\hline 028 & 0 & I & II & 9 & 4 & 0 \\
\hline Total & 6I & 53 & & & & II \\
\hline
\end{tabular}

Table 2: Frequency of reading strategy purportedly used per participant. 
In general, the results show a trend that is in consonance with good readers (Pang, 2008) and this is revealed by the frequency hits for statements I-20 where very low hits are around points I, 2 and 6 of the Likert scale; the highest numbers are around points 3,4 and 5 on the Likert scale. Results have also revealed that almost none of the participants chose points I (I never do that) and 2 (I usually do not that) on the Likert scale for statements $2 \mathrm{I}-26$, where there is only one frequency hit for statements $2 \mathrm{I}, 22$ and 24 for point I on the Likert scale and I, 3 and 2 frequency hits for point 2 on the Likert scale for statements 22, 23 and 24 respectively: a positive sign indeed given that good LI and even FL readers must do what is precribed in the said statements reflecting reading strategy (See Pang, 2008). Another positive sign is the very low degree of uncertainty regarding what they would do or claim to do when reading as shown by the choices in the added point 6 on the Likert scale (I don't know), i.e. almost insignificant with only II hits when compared to hit choices in points $3-5$ on the Likert scale. It should be noted here that, without the 'sixth' point added to the 5-point Likert scale in SORS, it would have been impossible to find out about this variable.

Good readers as asserted by Pang (2008) use graphics, such as charts, figures, punctuation, as cues to help with text understanding, and a table, a chart or bullets as cues to summarize the structure of the text. This behaviour was somewhat contrary with my participants where the claims regarding the choices for statements 15 (= I use graphics like charts, figures, punctuation to help me understand the text) and I7 (= I use a table, a chart or bullet to summarize the structure of the text) are surprising - one would have expected readers to at least claim to use them. However, one cannot discount the possibility of misinterpretation of the statements reflecting reading given their low competency in the foreign language and may have thought that they were asked whether they made and/ or drew graphs, charts or diagrams themselves to help with their understanding of text and the structure of the text. One other unexpected choice made by participants is that regarding statement 7 (I ignore difficult sentence(s) and continue reading), where a number of participants claimed not to ignore difficult parts of the text (hit choices around point I on the Likert scale, I never do that). It is common for good readers to use context and or co-text to solve problems rather than spend much needed time resolving difficult sentences, i.e. trying to find out the meaning of the sentence and not of a hard word and or lexical item. The results also confirm a long standing observation where readers tend to translate words into their mother tongue or the lingua franca, i.e. Portuguese: quite a significantly high level of frequency hits revolved around point 3 on the Likert scale (I do that sometimes) for statement 3 (I translate words into Portuguese while reading). In Table 3 below the dots refer to the times a choice was selected by the participants. I have termed this frequency hits per choice (I-6). Frequency hits show the degree of claims per strategy purportedly used by the participants and to which they claim to resort when resolving a particular reading problem. This table provides a detailed picture of participants' claims regarding their use of reading strategies. The claims as reflected in their totality above (total in Table I) are shown per statement and in their respective Likert scale. Some of the frequency hits have been boxed to reflect a specific point of interest which is matched to 
one or more factors in the research on reading comprehension and strategy usage in the field. It is possible to provisionally note that frequency hits on the Likert scale columns seem to match strategies associated with good readers, although this cannot be stated with certainty at this stage. There is a need to assert the fact that the (claimed) effective use of reading strategies can be checked against actual strategy use in think-aloud protocols (see Cabinda 20I4: Chapter 7). What can be asserted with more certainty is that the low frequency hits of the box around point I of the Likert scale 'I never do that' (statements I-3) shows that participants claim to be conscious of using text, context and co-text to assist them in meaning construction, and this is a positive sign since it is a practice adopted by high ability readers in LI and L2/ESL. Moreover, the box around point I on the Likert scale (statements $\mathrm{I5}^{-17}$ ) shows a rather different picture: here a substantial number of participants show a lack of use of a cluster of strategies associated with the successful reading of academic texts, i.e. the ability to use multimodal or visual elements to assist with the interpretation of texts.

\begin{tabular}{|c|c|c|c|c|c|c|c|}
\hline \multirow{2}{*}{ 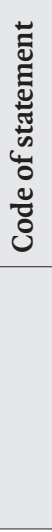 } & \multirow{2}{*}{ 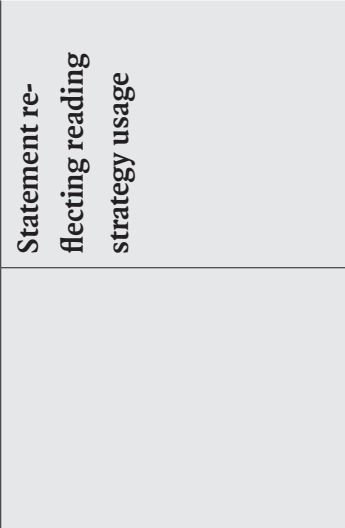 } & \multicolumn{6}{|c|}{ HOW TRUE? TOTAL statements circled/crossed } \\
\hline & & 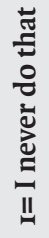 & 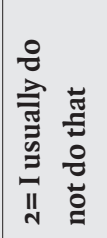 & 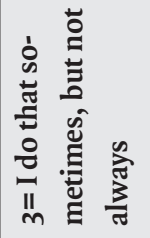 & 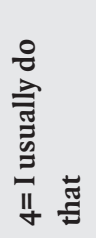 & 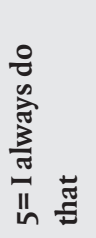 & 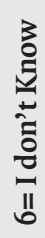 \\
\hline I & $\begin{array}{l}\text { I guess meanings of new } \\
\text { words using context. } \\
\text { MET9 }\end{array}$ & . & $\ldots$ & $\ldots$ & .......... & $\cdots$ & \\
\hline 2 & $\begin{array}{l}\text { I guess meanings of new } \\
\text { words using clues from } \\
\text { word root or affixation. } \\
\text { COGI2 }\end{array}$ & . & & .............. & ...... & .. & \\
\hline 3 & $\begin{array}{l}\text { I assess the need to check } \\
\text { the meaning in a dictio- } \\
\text { nary or to ignore words } \\
\text { that I don't know and } \\
\text { continue reading. COG9 }\end{array}$ &.. & $\cdot$ & ................ & $\cdots$ & $\cdots$ & \\
\hline
\end{tabular}




\begin{tabular}{|c|c|c|c|c|c|c|c|}
\hline 4 & $\begin{array}{l}\text { I find words with similar } \\
\text { meaning to replace } \\
\text { [difficult] words to help } \\
\text { me understand the text. } \\
\text { SUP }_{3}\end{array}$ & & $\ldots$. & .... & ....... & $\cdots \cdot$ & \\
\hline 5 & $\begin{array}{l}\text { I identify key words/ } \\
\text { expressions used by the } \\
\text { author to organize text } \\
\text { MET4 }\end{array}$ & & . & $\ldots$ & ........... & $\ldots$ &.. \\
\hline 6 & $\begin{array}{l}\text { I read difficult sentence } \\
\text { (s) repeatedly until I un- } \\
\text { derstand then I continue } \\
\text { reading the rest of the } \\
\text { text. COGII }\end{array}$ & .... & $\ldots$ & 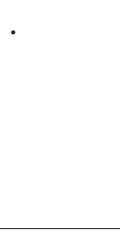 & $\ldots . .$. & $\ldots .$. & \\
\hline 7 & $\begin{array}{l}\text { I ignore difficult sentence } \\
\text { (s) and continue reading. } \\
\text { MET5 }\end{array}$ & ........ & $\ldots$ & $\ldots \ldots$ & & $\cdot$ & · \\
\hline 8 & $\begin{array}{l}\text { I analyse the grammatical } \\
\text { structure of a difficult } \\
\text { sentence to understand } \\
\text { the message. COGio }\end{array}$ & & $\cdots$ & $\ldots \ldots .$. & $\cdots \cdot$ & $\cdots$ & $\cdot$ \\
\hline 9 & $\begin{array}{l}\text { I make note-cards or files } \\
\text { after reading a text to } \\
\text { remember/revise details } \\
\text { about the text. } \mathrm{SUP}_{3} / \mathrm{SRS}\end{array}$ & $\cdots$ &.. & $\ldots \ldots$ & $\cdots$ & $\ldots .$. & \\
\hline Io & $\begin{array}{l}\text { I take notes while rea- } \\
\text { ding. SUPI }\end{array}$ & . & & ….............. & $\ldots$ & $\ldots$ & \\
\hline II & $\begin{array}{l}\text { I highlight/underline im- } \\
\text { portant sentences/parts } \\
\text { of the text while reading. } \\
\text { SUP2 }\end{array}$ & & & $\ldots$ & $\ldots$ & .................... & \\
\hline I2 & $\begin{array}{l}\text { I say the words out loud } \\
\text { or pronounce them in } \\
\text { my mind while reading. } \\
\text { COG2 }\end{array}$ & $\cdots$ & & $\ldots .$. & .. & ............ & \\
\hline I3 & $\begin{array}{l}\text { I translate words into } \\
\text { Portuguese while rea- } \\
\text { ding. SRS }\end{array}$ & $\cdots$ & $\cdots$ & $\cdots \cdots$ & $\ldots \ldots$ & .. & \\
\hline I4 & $\begin{array}{l}\text { I scan the text for pur- } \\
\text { pose before reading for } \\
\text { details .MET2/MRS }\end{array}$ & $\cdots$ & $\cdots$ & $\ldots \ldots$ & $\cdots \cdots$ &.$\cdot$ & \\
\hline
\end{tabular}




\begin{tabular}{|c|c|c|c|c|c|c|c|}
\hline I5 & $\begin{array}{l}\text { I use graphics like charts, } \\
\text { figures, punctuation to } \\
\text { help me understand the } \\
\text { text. MET8 }\end{array}$ & ................ & .. & ..... & . & & . \\
\hline I6 & $\begin{array}{l}\text { I recognize the structure } \\
\text { or organization of a text. } \\
\text { MET4 }\end{array}$ & . &.. &.. & $\ldots$ & $\ldots$. & .. \\
\hline I7 & $\begin{array}{l}\text { I use a table, a chart or } \\
\text { bullet to summarize } \\
\text { the structure of the text } \\
\text { MET6 }\end{array}$ & $\ldots \ldots$. & $\ldots$ & $\ldots .$. & . & . & .. \\
\hline I8 & $\begin{array}{l}\text { I use key words or topic } \\
\text { sentences to make pre- } \\
\text { dictions. MET9+Io/MRS }\end{array}$ &.. &.. & $\ldots \ldots$ & $\ldots \ldots$ & $\ldots$ & . \\
\hline I9 & $\begin{array}{l}\text { I make up imaginary } \\
\text { scenes or conjure sce- } \\
\text { narios with words while } \\
\text { reading. COG8 }\end{array}$ &.. & $\ldots .$. & $\ldots .$. & $\ldots .$. & . & . \\
\hline 20 & $\begin{array}{l}\text { I read sentence by sen- } \\
\text { tence to understand a } \\
\text { paragraph. } \mathrm{COG}_{3}\end{array}$ & $\ldots .$. & $\ldots$ & $\ldots \ldots$ &.. & $\ldots$ & . \\
\hline $2 \mathrm{I}$ & $\begin{array}{l}\text { I skim the text to get a } \\
\text { general idea and scan } \\
\text { for specific details while } \\
\text { reading to comprehend a } \\
\text { text.SUP5 }\end{array}$ & . & & $\ldots \ldots$ & $\ldots \ldots$ & $\ldots \ldots .$. & \\
\hline 22 & $\begin{array}{l}\text { I use prior knowledge to } \\
\text { understand new informa- } \\
\text { tion COGI }\end{array}$ & . & . & $\ldots \ldots$ & $\ldots \ldots$. & $\ldots .$. & \\
\hline 23 & $\begin{array}{l}\text { I set a goal/purpose be- } \\
\text { fore reading a text METI }\end{array}$ & & $\ldots$ & $\ldots .$. & $\ldots . .$. & $\ldots .$. & $\cdot$ \\
\hline 24 & $\begin{array}{l}\text { I vary my reading ap- } \\
\text { proach/style with each } \\
\text { text and according to } \\
\text { goal or purpose.COG } 5\end{array}$ & . &.. & . & ............ & $\ldots . .$. & . \\
\hline 25 & $\begin{array}{l}\text { I reflect upon what has } \\
\text { been learnt from the text } \\
\text { and apply results criti- } \\
\text { cally. COG7 }\end{array}$ & & & $\ldots \ldots$ & $\ldots \ldots$ & .......... & \\
\hline
\end{tabular}




\begin{tabular}{l|l|l|l|l|l|l}
\hline 26 & $\begin{array}{l}\text { I identify my weakness to } \\
\text { improve reading ability } \\
\text { MRS }\end{array}$ & & $\ldots$ & $\ldots . .$. & $\ldots . . . . . .$. & \\
\end{tabular}

Table 3: Overall total of frequency hits per statement reflecting reading strategy us.

The fact that a large number of participants claimed never to use text features such as charts, figures (multimodal elements) and punctuation (syntactic parsing) to help them understand is surprising, given that these are listed as the dimensions and characteristics of a good reader (Pang, 2008). Another interesting finding is reflected in the box around statements 2I-26, which shows that almost all participants are conscious of their reading processes and regulate these. In addition, there are two horizontal bands across all scales highlighted in the table (statements 9 and 12) which reflect a picture long asserted for LI readers at their early stage of acquisition of reading ability and in some readers at secondary school. This aspect is discussed further. The data revealed here were also used to rate the most used and least used strategies by FL learners.

In order to rank and determine the most and least purportedly used reading strategies I have grouped and added the frequency hits for each category and found a mean. To show a positive trend, i.e. in consonance with the behaviour of good readers, statements on the Likert scales 2 to 5 separated from I and 3 which shows grounds for a negative trend classification; here participants claim to never do a certain action - which is known to be a dimension and or a characteristic of a good reader. The mean showed that the most frequently self-reported sequence of reading strategies is reflected in numbers 26 (MRS ${ }^{4}$ - identify my weakness to improve reading ability), $25\left(\mathrm{COG}^{5} 9-\right.$ evaluating what is read), 2 (COGI2 - guessing meaning/MET ${ }^{6} 7$ - using context clues), 2I (MET2 - previewing text before reading), and $\mathrm{II}_{(\mathrm{SUP}}$ - underlining information in text), whereas numbers $20\left(\mathrm{COG}_{3}\right.$ - reading slowly and carefully/COG 5 - adjusting reading rate), I7 (MET8 - using typographical aids in summarising), 7 (COG4), I5 (MET6 - using visual or multimodal text features) and $\mathrm{I}_{6}\left(\mathrm{MET}_{4}\right.$ - noting text structure) are the least used.

\section{Discussion}

It should be remembered that the study attempted to assess the degree of purported use of reading comprehension skills and strategies and the degree of awareness participants have of their own use of such reading comprehension skills and strategies. Further, there was also an attempt to fill the gap advanced by Bernhardt's third dimension in her (20II) compensatory model of reading in a foreign language. As such, I have resorted to the data yielded above and present below a discussion in the hope of shedding

The term MRS refers to a classification category of reading strategies designated as Metacognition Reading Strategy (Sheorey \& Mohktari, 200I, and reflects metacognitive knowledge and/or metacognitive awareness (Flavell, 1976; Wenden, I991; Zhang, 200I; and Chamot, 2005). 
some light on the $50 \%$ unexplained variance.

Sheorey and Mokhtari's (200I) study which dealt with the differences in metacognitive awareness of reading strategies among native and non-native readers will be used to provide a basis for comparison. The study revealed ro out of 28 strategies to be of medium usage by the ESL students and none of these were reported to be used with low frequency (mean values below 2.4), whereas for the US students, eight strategies (29\%) fell in the high usage category (mean of 3.50 of higher), I 8 strategies (64\%) fell in the medium usage group, and the remaining two strategies (7\%) had means below 2.50. Using SORS, Sheorey and Mokhtari (200I) revealed a 'moderate overall use of reading strategies' and the 'observed difference in the overall means of the two groups' was statistically significant ( $\mathrm{t}$ [298] = $3.08 ; \mathrm{p}<0.05$ ). In brief their study shows that (i) the major (statistically significant) distinction between US and ESL students' reported usage of strategies is in the category of support reading strategies (SRS), the ESL group mean for SRS being considerably higher than the US group mean for the same category $(\mathrm{p}<0.002)$; (ii) irrespective of their reading ability or gender, both US and ESL learners attribute the same order of importance to cognitive, metacognitive, and support strategies; (iii) US and ESL highreading-ability students show comparable degrees of higher reported usage for metacognitive and cognitive reading strategies than lower-reading-ability students in the respective groups.

Comparatively, however, the study revealed that while US high-reading-ability students seem to consider support reading strategies to be relatively more valuable than low-reading-ability US students, ESL students attribute high value to support reading strategies, regardless of their reading ability level.

My study has revealed that the most used reading strategies are a mix of Metacognitive Reading Strategies and Cognitive Reading Strategies where the trend shows that EFL students are preoccupied in identifying own weakness, previewing text before reading to improve reading ability and evaluate the reading process (what is read) and a high degree of meaning guessing of context clues and underlining information in text are seen as highly used resources to attain comprehension.

These strategies (Pang 2008) show a trend in which the reader is preoccupied in securing that (s)he is never unconscious of the steps he/she takes but at the same time this can distract him/her from the main aim, comprehension. For instance, as has been revealed above, the high frequency of non-use of text features, i.e. charts, figures (multimodal elements) and punctuation (syntactic parsing) is a handicap given that Pang (2008) considers them dimensions and characteristics of a good reader. The study showed that those high-reading ability strategies for LI and ESL, mostly cognitive and metacognitive, were the least used.

When looking at my results and by comparing with Sheorey and Mokthari's (200I) conclusions I can state that the top five individual reading strategy preferences of ESL and US students show a preference for cognitive strategies followed by support strategies (Sheorey \& Mokhtari, 200I:439). The results in my study, still of purported use of reading strategies, show a similar trend in terms of categories, but positioned in an inverse 
order from that of Sheorey and Mokhtari's (200I): Both US and ESL learners attribute the same order of importance, irrespective of their reading ability or gender, to cognitive, metacognitive, and support strategies when reading academic texts. However, these are not the same as those for FL readers in my study. For instance, in a descending sequence, from top to bottom, a trend revealed reading strategies reflected in numbers 26 (MRS 'Identify my weakness to improve reading ability'), 25 (COG9-'Evaluating what is read'), 2 (COGI2 - 'Guessing meaning'/MET7 -'Using context clues'), 2I (MET2 - 'Previewing text before reading') and II(SUP2 - 'Underlining information in text') at the top, and at the bottom, frequency hits results show reading strategies $20\left(\mathrm{COG}_{3}-\right.$ 'Reading slowly and carefully'/COG5 - 'Adjusting reading rate'), I7 (MET8 - 'Using typographical aids'), 7 (COG4), I5 (MET6 - 'Using text features'), and I6 (MET4 - 'Noting text characteristics') as the least used. The table below shows the comparison above referred to:

\begin{tabular}{|c|c|c|}
\hline US students $(n=150)$ & ESL students (n=I52) & FL students ( $n=28$ ) (my study) \\
\hline Name Strategy & Name Strategy & Name Strategy \\
\hline \multicolumn{3}{|l|}{ Top five } \\
\hline $\begin{array}{l}\mathrm{COG}_{4} \text { Trying to stay focused } \\
\text { on reading }\end{array}$ & $\begin{array}{l}\text { COGII Re-reading for better } \\
\text { understanding }\end{array}$ & $\begin{array}{l}\text { MRS }{ }^{\star} \text { Identify my weakness to } \\
\text { improve reading ability }\end{array}$ \\
\hline \multirow[t]{2}{*}{$\begin{array}{l}\text { COG6 Paying close attention } \\
\text { to reading }\end{array}$} & $\begin{array}{l}\text { COG6 Paying close attention } \\
\text { to reading }\end{array}$ & COG9 Evaluating what is read \\
\hline & $\begin{array}{l}\mathrm{COG}_{4} \text { Trying to stay focused } \\
\text { on reading }\end{array}$ & $\begin{array}{l}\text { COGI2 Guessing meaning } \\
\text { of unknown words/ MET7- } \\
\text { using context clues }\end{array}$ \\
\hline \multirow[t]{2}{*}{$\begin{array}{l}\text { MET8 Using typographical } \\
\text { aids (e.g. italics) }\end{array}$} & $\mathrm{COG}_{5}$ Adjusting reading rate & $\begin{array}{l}\text { MET2 Previewing text before } \\
\text { reading }\end{array}$ \\
\hline & COGI Using prior knowledge & \\
\hline $\begin{array}{l}\text { COG }_{5} \text { Adjusting reading rate } \\
\text { COGII } \\
\text { Re-reading for better under- } \\
\text { standing }\end{array}$ & & $\begin{array}{l}\text { SUP2 Underlining informa- } \\
\text { tion in text }\end{array}$ \\
\hline \multicolumn{3}{|l|}{ Bottom five } \\
\hline $\begin{array}{l}\text { SUP }_{5} \text { Going back and forth } \\
\text { in text }\end{array}$ & $\begin{array}{l}\text { SUP4 Paraphrasing for better } \\
\text { understanding }\end{array}$ & $\begin{array}{l}\mathrm{COG}_{3} \text { Reading slowly and } \\
\text { carefully/COG5Adjusting } \\
\text { reading rate }\end{array}$ \\
\hline $\begin{array}{l}\mathrm{SUP}_{3} \text { Using reference mate- } \\
\text { rials }\end{array}$ & $\begin{array}{l}\mathrm{MET}_{4} \text { Noting text characte- } \\
\text { ristics }\end{array}$ & $\begin{array}{l}\text { MET8 Using typographical } \\
\text { aids }\end{array}$ \\
\hline $\begin{array}{l}\text { SUP4 Paraphrasing for better } \\
\text { understanding }\end{array}$ & $\begin{array}{l}\text { COG2 Reading aloud when } \\
\text { text becomes hard }\end{array}$ & $\begin{array}{l}\mathrm{COG}_{4} \text { Trying to stay focused } \\
\text { on reading }\end{array}$ \\
\hline $\begin{array}{l}\text { SUP6 Asking oneself ques- } \\
\text { tions }\end{array}$ & $\begin{array}{l}\text { SUP6 Asking oneself ques- } \\
\text { tions }\end{array}$ & MET6 Using text features \\
\hline
\end{tabular}




\begin{tabular}{l|l|l}
\hline $\begin{array}{l}\text { SUPI Taking notes while } \\
\text { reading }\end{array}$ & $\begin{array}{l}\text { SUPI Taking notes while } \\
\text { reading }\end{array}$ & $\begin{array}{l}\text { MET4 Noting text characte- } \\
\text { ristics }\end{array}$
\end{tabular}

*MRS Identify my weakness to improve reading ability'

Table 4: Reported reading strategies used most and least by US and ESL students and FL students ${ }^{8}$

Adapted from Sheorey \& Mokhtari, 2001:439).

A closer look at the bottom five reading strategies of the FL participants certainly pinpoints an inverse trend: what US and ESL students in Sheorey and Mokhtari's (200I) study consider higher order reading strategies, are the low order reading strategies according to the FL students in my study. These are $\mathrm{COG}_{3}$, 'Reading slowly and carefully'/ COG5 'Adjusting reading rate' (20), MET8, 'Using typographical aids' (I7), COG4, 'Trying to stay focused on reading' (7), MET6, 'Using text features' (I5), and MET4, 'Noting text characteristics' (I6). COG $4, \mathrm{COG}_{5}$ and COGII are at the very top of the US and ESL list while they are at the very bottom of the FL participants.

Clearly, the effective use of reading strategies in Sheorey and Mokthari (200I) contrasts with the purported use of the same strategies in my study. This suggests the need for a study to assess the effective use of these strategies by EFL readers. There is, however, a clear indication of a conscious awareness regarding the use of reading strategies, even when only a few participants could clearly name specific reading strategies as classified in reading taxonomies, such as those by Munby (I980), Rosenthine (I980), Weir (I984), Sheorey and Mokhtari (200I).

The purportedly used or 'perceived' to be used reading strategies fall onto three types of categories: language knowledge and processing ability, i.e. word recognition, proposition formation, semantics awareness of text structure, etc., Cognitive ability, i.e. the use of prior knowledge, mother tongue, etc., and Metacognitive strategic competence. As has been mentioned, although these strategies are consistent with those used by good readers (Pang 2008:II). It should be noted that the participants in my study do perceive themselves to use such strategies. In the latter category, metacognitive strategic competence, for instance, the participants claimed to monitor comprehension process, evaluating and regulating strategy use to achieve maximum comprehension (numbers \#24, 25 and 26 in the questionnaire part II).

The claims above are consonant with the use of a number of important strategies for reading comprehension (setting the purpose for reading, prediction, summarizing, questioning, use of text structural features, self-monitoring) which readers/learners in general use to a greater degree to plan, control and evaluate their own understanding of text. Sheorey and Mokhtari (200I), Mokhtari and Reichard, (2004), Schoonen et al. (I998) and Stevenson et al. (2003) found the listed strategies to have been used by the

It was very difficult to classify this strategy for none of the taxonomies had a code that closely enough matched this statement as single entity; it was deemed a Metacognitive Reading Strategy for the fact that the reader is aware/conscious of his/her own problems and seeks to consciously solve them. 
participants in their studies to regulate their own reading process and the processing of meaning. In order to be able to come to similar conclusions in this study further evaluation is necessary, especially of the effectively used reading strategies.

As mentioned above, good readers make strategic and skilful use of various reading strategies to monitor and regulate their own use of reading strategies with reference to the on-going comprehension process (Pang, 2008:9). Results from the FL participants would suggest that their use is consonant with a high degree of frequency for support strategies and cognitive reading strategies (mostly used by good readers) resulting in a higher tendency to achieve the overall meaning of the text more successfully than do poor readers (Sheorey \& Baboczky, 2008).

However, the trend shown of top-down use and self-awareness of a whole battery of reading strategies is in contradiction with the negative mean score result of the IELTS reading comprehension test: only $16.57 \%$ (Cabinda, 2013).

Despite the above facts, the picture above is inconclusive still given that it cannot be claimed a definite true reflection of FL readers in the multilingual context of UEM. The small sample used in the study does reveal a clear indication of the position of each category, where Metacognitive Reading Strategies (MRS) and Support Reading Strategies (SRS) ${ }^{9}$, and to a lesser extent metacognitive and supply strategies (MET and SUP in Sheorey \& Mokhtari's 200I classification) are claimed to be chiefly used.

This trend, coupled with the one shown in the rank of statements reflecting reading strategy usage, leads me to claim the existence of a serious reading problem amongst my research sample and perhaps amongst students at UEM dealing with foreign language texts.

\section{Conclusions}

The main aims of the present study were twofold: i) to assess the degree of purported use of reading comprehension skills and strategies in a foreign language (English), and ii) assess the degree of awareness participants have of their own use of reading comprehension skills and strategies.

At this stage of the research I should conclude by affirming that the findings show that the participants show a self-reported use of a battery of cognitive, metacognitive and supply reading strategies, with very few and insignificant exceptions among them, and that they can be compared to good or high ability readers.

The study confirmed that the participants are aware of the existence of reading strategies and seem to consciously use them in their daily reading processes, but at this stage one cannot conclusively claim that the reading strategies are used effectively. Confirmation from the findings supported the idea of the unique particularity of FL bilingual readers in terms of using cognates, translation and code-switching.

One particular finding was related to the claimed regulated-to-sophisticated use of reading strategies for task resolution. Here a trend of use of top-down to compensatory 
reading strategies, and self-awareness of a battery of reading strategies, could be observed from the results - which would mean readers with a high to moderate capacity to comprehend text and possibly high levels of performance in reading tests. The trend was however in contradiction to the negative mean level of test comprehension as mirrored in the IELTS reading comprehension test results, which showed a negative trend (Cabinda, 2013) - an issue to be studied in the future.

Finally, the findings have revealed that participants claimed to use a battery of reading strategies that do not find a parallel in high ability readers in LI and L2; the picture in my study is somewhat contrary to that model, where the trend shows that metacognitive and supply strategies seem to be chiefly used rather than cognitive strategies as is the case of LI and L2 (within the context where the target language, LI, is English).

There are no Holy Grail answers to the issues posited at the outset of the present study and clearly only an association of all the variables, looked at in a non detached perspective, could assist in bringing to light some factors that could be used to fill in the gap of the ' $50 \%$ unexplained variance' in Bernhardt's (20II) compensatory model.

I have shown that no correlation can be found between the purported use of a battery of reading skills by FL readers and their text comprehension. This in turn, perhaps due to a lack of L2 linguistic knowledge, resulted in the purported use of supply strategies such as translation, and this, perhaps due to their lack of knowledge of text structure or discipline specific vocabulary, led them to be very timid and shy readers with low levels of text comprehension.

Despite the substantial battery of strategies reported, I have concluded that Mozambican FL participants resort to a high use of LI (Portuguese or other) related reading strategies and this shows that they behave rather differently from English LI readers and the high frequency of reading skills and strategies does not make these FL readers effective ones.

\section{References}

Alderson, J.C. (I984). Reading in a Foreign Language: a reading problem or a language problem? In J. C. Alderson and A. H. Urquart (eds.), Reading in a Foreign Language. London: Longman. (2000). Assessing Reading. Cambridge: Cambridge University Press.

Bernhardt, E.B. (I986a). Cognitive processes in L2: An examination of reading behaviors. In J. Lantolf \& A. Labarca (Eds.), Delaware symposium on language studies: Research on second-language acquisition in a classroom setting (pp. 35-5I). Norwood, NJ: Ablex.

(I986b). Reading in the foreign language. In B. H. Wing (Ed.), Listening, reading and writing: Analysis and application (pp. 93-II5), Middlebury, VT: Northeast Conference on the Teaching of Foreign Languages.

(I99I). Reading development in a second-language. Norwood, NJ: Ablex.

(2005). Progress and procrastination in Second Language Reading. Annual Review of Applied Linguistics (2005) 25, 133-I50. Printed in the USA. Copyright $\odot$ 2005, Cambridge University Press 02671905/05.

Bernhardt, E.B. \& Kamil, M. L. (1995). Interpreting relationships between L1 and L2 reading: Consolidating the linguistic threshold and the linguistic interdependence hypothesis. Applied Linguistics, I6, I5-34.

Bernhardt, E.B. (20II). Understanding advanced second-language reading. New York: Routledge. 
Block, C.C. \& Israel, S.E. (2004).'The ABCs of performing highly effective think-alouds'. The Reading Teacher 58(2), I54-167.

Block, D. (2003). The Social Turn in Second Language Acquisition. Edinburgh University Press.

Brown, J.D. \& Rodgers, T.S. (2009). Doing Second Language Research. Oxford University Press.

Brunfaut, T.S.J. (2008). 'Foreign Language Reading for Academic Purposes. Students of English (Native Speakers of Dutch) Reading English Academic Texts.' Unpublished PhD Dissertation. University of Antwerpen, 2008. Faculteit Letteren en Wijsbegeerte Departement.

Cabinda, M. (1996). Killing the Hydra: First Language Influence on foreign language reading. Unpublished MA Thesis, 1996. The University of Liverpool, UK.

(1997). Paper on First Language influence on Foreign Language Reading, ETC Conference - English Language Connect Conference, Witswaterand University, RSA.

(I998). Paper on Course and Curriculum Design at Tertiary Level: What pathway takes you through the Maze?, English at the Turn of the Millennium Conference, Johannesburg College of Education, RSA.

_ (2013). The need for a needs analysis at UEM: Aspects of and attitudes towards change. Linguistics and Education. Available at http://dx.doi.org/ro.ror6/j.linged.2013.10.00I

(20I4). 'Identifying Academic Reading Strategies in a Multilingual Context'. Unpublished PhD Thesis. The University of the Westeren Cape, Faculty of Education. South Africa.

Carrell, P.L. \& Wallace, B. (I983). Background Knowledge: context and familiarity in reading comprehension. In M.A. Clarke and J. Handcombe (Eds.), On Tesol '82: Pacific Perspectives on Language Learning and Teaching, pp. 295-307, Teachers of English to Speakers of Other Languages, Washington, D.C.

Carrell, P.L. (I98I). The role of Schemata in L2 comprehension, paper presented at the Fifteenth Annual Convention of TESOL. Detroit, Michigan, March, I98I.

(I99I) Second-language reading: Reading ability or language proficiency? Applied Linguistics I2, I59-I79.

Carrell, P.L., Devine, J. and Eskey, D. (I988). Interactive approaches to second-language reading. Cambridge: Cambridge University Press.

Clarke, M. (1979). 'Reading in Spanish and English: Evidence from adult ESL Students' Language Learning, 29, I2I-I5O.

Coady, J. (1979). A Psychoinguistic Model of The ESL reader. In R. Mackay, B. Barkman and R. R. Jordan (eds), Reading in a Second Language. Rowley, Mass.: Newbury House, 5-I2.

Cohen, L., Manion, L. and Morrison, K. (20II). Research Methods in Education. Routledge, New York, USA.

Coleman, M. and Briggs, A.R. J.(Eds) (2005). Research Methods in Educational Leadership and Management. Sage publications, London, UK.

Cowan, J. R. and Sarmad, Z. (1976). 'Reading performance of bilingual children according to type of school and home language'. Language Learning, 26, 353-376.

Crutcher, R.J. (1994) 'Telling what we know: The use of verbal report methodologies in psychological research.' Psych. Sci. 5:24I-244.

Cummins, J. (1979). ‘Cognitive/Academic Language Proficiency, Linguistic Interdependence, The Optimum Age Question and some Other Matters' Working Papers on Bilingualism, 19, 107-205.

Feng, X. \& Mokhtari, K. (1998). Strategy use by native speakers of Chinese reading easy and difficult texts in English and Chinese. Asian Journal of English Language Teaching, 8, I9-40.

Grabe, W. (2009). Reading in a Second Language: Moving From Theory to Practice. New York: Cambridge University Press.

Grabe, W. \& Stoller, F.L. (20II) Teaching and Researching: Reading, 2nd Edition. Pearson Education ESL. Copyright $\odot$ 20II).

(2002). Teaching and researching reading. New York:Longman. 
Hosseini, N.N. (2006). On the meta-cognitive awareness of reading strategies and the reading comprehension of Iranian nonEnglish major university students. Unpublished Master's thesis, Al-Zahra University, Tehran, Iran. Available at: http://exchanges.state.gov/education/engteaching/pubs/BR/functionalsec 4_Io.htm

Jiménez, R.T., García, G.E., \& Pearson, P.D. (1996). The Reading Strategies of Bilingual Latina/o students who are successful English readers: Opportunities and obstacles. Reading Research Quarterly, 3I, 90-II2.

(1995). Three Children, Two Languages, and Strategic Reading: Cases Studies in Bilingual /Monolingual Reading. American Educational Research Journal, 32, 67-97.

Jiang, B. and Kuehn, P. (200I). Transfer in the Academic language development of post-secondary ESL students. Bilingual Journal, 200I - neiu.edu.

Jobe, J. B. and Mingay, D. J. (I989). Cognitive Research Improves Questionnaires. AJPH, August 89, vol. 79(8).

Johnson, D. (1994). Research Methods in Educational Management. Essex, England. Longman Group UK Ltd.

Johnson, K. and Johnson, H. (I998). (eds) Encycloedic Dictionary of Applied Linguistics. Blackwell Publishers, Oxford, UK.

Johnson, P. (I98I) 'Effects on reading comprehension of language complexity and cultural background of a text', TESOL, I5, I69-8I. (I982). 'Effects on reading comprehension of building background knowledge'. TESOL, I6, 503-I6.

Jolly, D. (I978). 'The establishment of a self-access scheme for intensive reading'. Paper presented at the Goethe Institute, British Council Colloquium on Reading, Paris, October, 1978.

Just, M.A. \& Carpenter, P. A. (1987). Cognitive processes in comprehension. Hillsdale, New Jersey: Lawrence Erlbaum.

Kerfoot, C. (2009). Changing conceptions of literacies, language and development Implications for the provision of adult basic education in South Africa: Centre for Research on Bilingualism. Stockholm University Doctoral Dissertation, Centre for Research on Bilingualism, Stockholm University.

Kerfoot, C. \& Winberg, C. (1997). Learning about Action Research. Published by Juta \& Company Ltd, P.O. Box I4373, Kenwyn 7790, Cape Town, South Africa, in association with Uswe, P.O. Box 13085 , Mowbray 7705 @ Uswe, Cape Town. ISBN 0-702I-3893-2. Editors: Sandie Yahl and Rebecca Pointer. Printed and bound by MSP Security \& Digital Print (Pty) Ltd.

Klapper, P. (Igr6). Teaching Children to Read. New York: Appleton.

Machado, M.C. (1985). Reading in L2: An investigation on the role of background knowledge or schemata on comprehension. PhD dissertation, Georgetown University, Washington, D. C.

Mokthari, K. (1998). Strategy Use by University Students in Morocco. Research paper presented at the 32nd Annual TESOL Convention (March I7-2I), Seattle, WA, I998.

Mokhtari, K., \& Reichard, C. (2002). Assessing students' metacognitive awareness of reading strategies. Journal of Educational Psychology, 94 (2), 249-259.

(2004). Investigating the strategic reading processes of first and second language readers in two different cultural contexts. System 32 (2004) 379-394.

Munby, J. (1978). Communicative Syllabus Design. Cambridge: Cambridge University Press.

Naiman, N., Frohlich, M., Stern, H. and Todesco, A. (1987). 'The good language learner'. Research in education series, nO-7. Toronto: Ontario Institute for studies in Education.

Nassaji, H. (20II). Issues in Second-Language Reading: Implications for Acquisition and Instruction. Reading Research Quarterly, Vol. 46, No. 2 (April/May/June 20II), pp. 173-184. Published by: International Reading Association, Stable URL: http://www.jstor.org/stable/4I203420. Accessed: 29/II/2013 09:17.

Lynn, E. \& Huijie, L. (2008). Shift in Chinese EAP learner's perceptions of reading strategies. The EastAsian Learner, Vol2(I). Oxford Brooks University, UK and Harbin Institute of Technology, China. Available at http//owww.brookes.ac.uk/school/education/eal

O'Malley, J.M., Chamot, A.U., Stewner-Manzanas, G., Kupper, L. and Russo, R. (I985). 'Learning strategies used by beginning and intermediate ESL students'. In Language Learning, 35, 2I-46. 
Oliveira, V.Q.S.F. (I988). 'The relevance of background knowledge or schemata in EFL reading comprehension.' In the Especialist, vol. 9, n II2,97-IIO, I988.

Oxford, T., Bongaerts, T. and Kellerman, E. (I986). The use of retrospective verbal reports in analysis of compensatory strategies. In Faerch, C. and Kasper, G. (Eds.), Introspection in Second Language Research. Clevedon, UK: Multilingual Matters, 213-229.

Oxford, T., Nyikos, M. and Crookall, D. (1987). 'Learning strategies of University Foreign Language students: A large-scale study'. Washington, DC: Center for Applied Linguistics.

Pang, J. (2008). Research on good and poor reader characteristics: Implications for L2 reading research in China Reading in a Foreign Language April 2008, Volume 20, No. I ISSN I539-0578 pp. I-I8.

Perfetti, C.A. (1985). Reading Ability. Oxford University Press.

Perfetti, C.A. \& Lesgold, A.M. (1977). Discourse processing and sources of individual differences. In Patricia A. Carpenter \& Marcel Adam Just (eds.), Cognitive processes in comprehension (pp. I4I-I83). Hillsdale, New Jersey: Lawrence Erlbaum.

Poole, A. (2009). The reading strategies used by male and female Colombian University students. Profile, II, 29-40. available at http://redalyc.uaemex.mx/redalyc/pdf/I692/I692I4I44003.pdf

Potter, F. (I982). 'The use of the Linguistic context: Do good readers and poor readers use different strategies?' In British Journal of Educational Psychology, 52,I6ff23, 1982.

Presser, S. et al., (2004). Methods for Testing and Evaluating Survey Questions. The Public Opinion Quarterly, Vol. 68, No. I, pp. I09-Izo.

Pressley, M. \& Afflerbach, P. (1995). 'Verbal protocols of reading: The nature of Constructively Responsive Reading'. Hillsdale, NJ: Erlbaum.

Ramirez, A.F. (1986). 'Language learning strategies used by adolescents studying French in New York schools.' In Foreign Language Annuals. I9 (2), I3I-I4I.

Robeck, M.C. \& Wallace, R. R. (I990). The Psychology of Reading. CUP.

Saw, S.M. \&, Ng, T.P, (200I). The Design and Assessment of Questionnaires in Clinical Research. Singapore Medical Journal, 200I 42(3): I3I-I35.

Schoonen, R., Hulstijn, J. \& Bossers, B. (1998). Metacognitive and language specific knowledge in native and foreign language reading comprehension : an empirical study among Dutch students in Grades 6, 8 and 10. Language Learning, 48(I), 7I-Io6.

Sheorey, R. \& Baboczky, E. (2008). Meta-cognitive awareness of reading strategies among Hungarian college students. In K. MokhtariMokhtari \& R. Sheorey (Eds.), Reading strategies of first and second language learners (pp. I6I-I73). Norwood, MA: Christopher-Gordon.

Sheorey, R. \& Mokhtari, K. (200I). Differences in the meta-cognitive awareness of reading strategies among native and non-native readers. System, 29, 43I-449. Available at: http://dx.doi.org/ro.10I6/s0346-25x(oI)00039-2.

Smith, F. (1978). Reading. Cambridge University Press.

Soi Meng, P. (2006). Strategy use in advanced EFL readers: Identifying and characterizing the patterns of reading strategies employed by tertiary EFL students. Unpublished Doctoral dissertation, Chinese University of Hong Kong, Hong Kong. Available at: http://sunzi.lib.hku.hk/ER/detail/hkul/408083I

Stevenson, M., Schoonen, R. \& De Glopper, K. (2003). Inhibition or Compensation? A multidimensional comparison of reading processes in Dutch and English. Language Learning, 53(4), 765-815.

Suri, S. \& Verma, N. (2010). Questionnaire Validation Made Easy. European Journal of Scientific Research ISSN I450-2I6X Vol.46 No.2 (2010), pp.172-178. @ EuroJournals Publishing, Inc. 2010. Available at http://www.eurojournals.com/ejsr.htm. Accessed 06/09/20I2.

Vidal, R. T. (2002). Is there a correlation between reported language learning strategy use, actual strategy use and achievement? I Linguagem \& Ensino, Vol. 5, No. I, 2002 (43-73). Universidade Federal Fluminense.

Weir, C. J. (1984). Identifying the language needs of overseas students in Tertiary Education in the UK. Unpublished Phd Thesis, University of London. 
Wenden, A.L. (1986). 'What do second language learners know about their language learning? A second look at retrospective accounts'. In Applied Linguistics, 7 (2), I86-205.

(1985). 'Learner strategies'. In TESOL Newsletter, i9 (5), I-7.

Yang, Y.F. (2002). Reassessing Readers' Comprehension monitoring. Reading in a Foreign Language, $2002-$ nflrc.hawaii.edu.

(2006). Reading Strategies or Comprehension monitoring Strategies? Reading Psychology. Taylor \& Francis.

Yuko, I. (20II). The Effects of Metacognitive Reading Strategies: Pedagogical Implications for EFL/ESL Teachers. La Crosse. The Reading Matrix (c) 20II, Volume Ir, Number 2, April 20Ir. University of Wisconsin.

_ (2009). Meta-cognitive awareness and strategy use in academic English reading among adult English as a Second Language (ESL) students. Unpublished Doctoral dissertation, University of Southern Mississippi, United States. Available at http://www.proquest.com/en-US/products/dissertations/individuals. html.

Zhang, L.J. (200I). Awareness in reading: EFL students'metacognitve knowledge of reading strategies in an acquisition-poor environment. Language Awareness, 2002 - Taylor \& Francis.

Zhang, L.J. \& Wu, A. (2009). Chinese senior high school EFL students' meta-cognitive awareness and reading-strategy use. Reading in a Foreign Language, 2I(I), 37-59. 